\title{
Perception of cost-consciousness among medical students: an 11 -item scale
}

\author{
Percepção da custo-consciência entre estudantes de \\ Medicina: uma escala de 11 itens
}

\section{Marilia Menezes Gusmao', Marta Silva Menezes², Carolina Villa Nova Aguiar ${ }^{3}$, Liliane Lins ${ }^{4}$, Ana Marice Ladeia ${ }^{5}$, Luis Cláudio Correia ${ }^{6}$}

\begin{abstract}
'Author correspondence. BAHIANA - School of Medicine and Public Health, Salvador, Bahia, Brazil. ORCID: 0000-0002-7907-2503.mariliagusmao.pos@bahiana.edu.br 2BAHIANA - School of Medicine and Public Health, Salvador, Bahia, Brazil. ORCID: 0000-0001-7713-518X. martamenezes@bahiana.edu.br ${ }^{3}$ BAHIANA - School of Medicine and Public Health, Salvador, Bahia, Brazil. ORCID: 0000-0002-8213-3100. carolinaaguiar@bahiana.edu.br ${ }^{4}$ BAHIANA - School of Medicine and Public Health, Salvador, Bahia, Brazil. ORCID: 0000-0003-3736-0002. Ikusterer@gmail.com ${ }^{5}$ BAHIANA - School of Medicine and Public Health, Salvador, Bahia, Brazil. ORCID: 0000-0002-2235-7401. anamarice@bahiana.edu.br ${ }^{6}$ BAHIANA - School of Medicine and Public Health, Salvador, Bahia, Brazil. ORCID: 0000-0002-6910-1366. luisclcorreia@gmail.com
\end{abstract}

RESUMO | INTRODUÇÃO: Gerenciar recursos de saúde de maneira consciente é um importante desafio na educação médica. A utilização de escala de percepção de atitudes custo-conscientes pode ser útil para identificar pontos a serem melhorados em um grupo de alunos bem como avaliar os resultados de intervenções educacionais. OBJETIVO: Validar uma escala de avaliação da percepção da custo-consciência em estudantes de medicina. Método: A escala utilizada era composta de 13 itens, que foram submetidos às etapas de tradução, validação semântica e análise de suas características psicométricas (análise fatorial exploratória, alfa de Cronbach e teste de confiabilidade composta). RESULTADOS: A amostra contou com 275 participantes, dos quais $62 \%$ eram do sexo feminino, com idade média de $25 \pm 3,1$ anos. A melhor estrutura para medir as percepções dos estudantes foi a solução de um único fator, com 11 dos 13 itens sendo mantidos na versão final. Obteve-se um alfa de Cronbach substancial para este questionário $(0,66)$ e confiabilidade composta foi de 0,77. CONCLUSÃO: Os resultados sugerem que o questionário apresenta qualidade psicométrica satisfatória e, portanto, é capaz de mensurar a percepção de estudantes de medicina sobre atitudes custo-conscientes.

PALAVRAS-CHAVE: Educação médica. Estudo de validação. Profissionalismo. Custo-efetividade.

\begin{abstract}
I INTRODUCTION: Managing healthcare resources in a cost-conscious way is an important topic in medical education. A validated instrument to measure the perception of cost-conscious attitudes of medical students could be an important tool for university staff in understanding them and to plan and evaluate educational interventions to address them. OBJECTIVES: To validate a scale to measure the perception of cost-conscious attitudes among medical students. Method: Thirteen items from a survey to measure cost-conscious attitudes in medical students were used. Semantic validation and psychometric analysis (exploratory factor analysis, Cronbach alpha, and composite reliability test) were carried out. RESULTS: A sample of 275 participants, of which $62 \%$ were female, with an average age of $25 \pm 3.1$ years, completed the questionnaire. The best structure to measure the perceptions is the one-factor solution, with 11 of the 13 items remaining in the final version. Substantial Cronbach's alpha for this questionnaire was obtained 0.66 and composite reliability was 0.77 . CONCLUSION: The results suggest that the questionnaire has a satisfactory psychometric quality and is, therefore, able to measure the perception of medical students about cost-conscious attitudes.
\end{abstract}

KEYWORDS: Medical education. Validation studies. Professionalism. Cost-effectivity. 


\section{Introduction}

The cost-conscious management of healthcare resources is an important subject in the education of medical students and physicians. The cost of medical tests and procedures should reflect the principles of medical professionalism, from the patient's welfare to respect for the patient's autonomy and social justice?.

It is estimated that about $30 \%$ of total health costs are unnecessary and could be avoided without harming patient care ${ }^{2}$. Requests by doctors for low-value tests, treatments, and procedures are among the average sources of waste in healthcare ${ }^{3}$. According to Brazilian Ministry of Health data, there are requests for tests after 30 to $50 \%$ of outpatient visits to the Unified Health System (SUS), the Brazilian public healthcare system. ${ }^{4}$ Eliminating or at least reducing the waste from these poorly thought out medical decisions could result in improvements in safety and efficiency in treatment for patients, as well as bring benefits to the sustainability of the health care system.

To encourage more cost-effective medical decisions, it is important to raise awareness among physicians and medical students about this topic daily. The international campaign Choosing Wisely lists situations that occur frequently but that should be avoided $^{5}$.

Educational interventions to promote more costeffective thinking right from medical school are important in changing the behavior of our physicians. In Brazil, the Bahiana School of Medicine and Public Health (EBMSP) has been using an educational approach inspired by the Choosing Wisely campaign on their students and teachers ${ }^{6}$.

Society can benefit from cost-conscious attitudes in healthcare ${ }^{7}$. However, there is a lack of validated instruments to evaluate educational interventions to measure such attitudes. There are some validated cost-conscious perception scales for physicians ${ }^{2,7-10}$, but no validated scales appropriate for medical students have been found.
A survey was applied to 3,395 medical students in the United States to evaluate their perceptions of cost-consciousness' ${ }^{11}$. Although the questions were based on other cost-conscious validated scales for physicians ${ }^{8,9}$, the analysis of psychometric characteristics of the survey was not described by the authors.

A validated instrument can be useful to measure the perception of cost-conscious attitudes of medical students before and after educational interventions and to compare students exposed to different scenarios in their training. The purpose of this research is to validate a scale to assess the perception of cost-conscious attitudes among medical students.

\section{Methods}

\section{The instrument}

The questionnaire used in the study was based on a cost-consciousness perception survey originally published by Leep Hunderfund et $\mathrm{al}^{11}$. The 13 items categorized as "attitudes" were used in the proposed questionnaire. The questions used a fourpoint Likert scales for scoring, with the following choices: strongly disagree, moderately disagree, moderately agree, strongly agree. Other variables included in the instrument were age, semester of graduation and sex.

\section{Translation and semantic validation of the instrument}

The translation and semantic validation were performed according to the international standards ${ }^{12}$. The items, originally written in English, were translated into Portuguese by two independent bilingual Brazilian professional translators. A third translator, who is a native English speaker fluent in the Portuguese language, retranslated the reconciled version from Portuguese to English. The original version and the retranslation were then compared and considered equivalent. 
An expert committee, made up of teachers who were familiar with the construct, produced the prefinal version of the translation. Discrepancies were eliminated by consensus on all items. For semantic validation, a group of 11 third-year medical students also assessed the scale in Portuguese. The observations and suggestions made by them were taken into consideration in preparing the final version.

\section{Validation Process:}

The final version of the questionnaire was administered to medical students in their fifth and sixth year (the last two years of medical school in Brazil) at the Bahiana School of Medicine and Public Health from December 2016 to March 2017. The recommended sample size for exploratory factor analysis is of at least 10 participants per item in the questionnaire, or a minimum of 200 answered questionnaires $^{2}$. A sample size of 250 answered questionnaires was estimated, considering that some of the responses could be incomplete.

\section{Statistical Analysis}

Descriptive analysis of student characteristics was performed, assessing mean and standard deviation of continuous variable and frequencies of discrete variables such as sex and the year of the student on the course. Students that completed less than $80 \%$ of the questionnaire items were excluded from the analysis.

For construct validation, we performed exploratory factor analysis (AFE) with orthogonal varimax rotation and extraction by principal components. We performed factorability of the correlation matrix using the Kaiser-Meyer-Olkin (KMO) test and the Bartlett's test of sphericity. Values acceptable for the KMO were $>0.500$ and $p<0.05$ for the Bartlett test ${ }^{13}$.
Parallel analysis was used to estimate the maximum number of factors by comparing the empirically obtained eigenvalues (from the latent root criterion) to the eigenvalues generated by random matrices ${ }^{13}$.

The factor solutions were tested, and the items with a factor loading of less than 0.3 or conceptual ambiguity were excluded. Composite reliability and Cronbach's alpha were calculated to assess the instrument's precision, acceptable values were considered above 0.7014 and 0.6115 , respectively. The software used for analysis was SPSS $v 21.0$ for Windows.

\section{Ethical considerations:}

This study was approved by the Ethical Board of Bahiana School of Medicine and Public Health, CAEE number 57164216.1.0000.5544.

\section{Results}

The result of the translation of the 13 items is shown in Chart 1.

A total of 500 questionnaires were sent to the medical students, and 275 students answered and returned them. Eight incomplete questionnaires were excluded, and the final sample used for the psychometric analysis was 267 questionnaires. One hundred and sixty-eight $(62 \%)$ of the students were female, mean age $25 \pm 3,1$ years old. The distribution of students according to semester were: $22.5 \%$ in the ninth semester, $27 \%$ were in the tenth semester, $28.8 \%$ were in the eleventh semester and $21.7 \%$ were in the 12 th semester. 


\begin{tabular}{|c|c|}
\hline Original & Translation to Portuguese \\
\hline $\begin{array}{l}\text { Physicians should... } \\
\text { 1. Take a more prominent role in limiting use of } \\
\text { unnecessary tests }\end{array}$ & $\begin{array}{l}\text { Os médicos devem... } \\
\text { 1. Ter um papel mais importante na limitação do uso de } \\
\text { exames desnecessários }\end{array}$ \\
\hline $\begin{array}{l}\text { 2. Try not to think about the cost to the health } \\
\text { care system when making treatment decisions }\end{array}$ & $\begin{array}{l}\text { 2. Tentar não pensar sobre o custo para o sistema de } \\
\text { saúde quando tomar decisões terapêuticas }\end{array}$ \\
\hline $\begin{array}{l}\text { 3. Be aware of the costs of the tests or } \\
\text { treatments they recommend }\end{array}$ & $\begin{array}{l}\text { 3. Estar cientes dos custos dos exames ou tratamentos } \\
\text { que são recomendados por ele }\end{array}$ \\
\hline $\begin{array}{l}\text { 4. Talk to patients about the costs of care when } \\
\text { discussing treatment options }\end{array}$ & $\begin{array}{l}\text { 4. Conversar com os pacientes sobre os custos ao discutir } \\
\text { opções de tratamento. }\end{array}$ \\
\hline $\begin{array}{l}\text { 5. Change their clinical practices (e.g., ordering, } \\
\text { prescribing) if the cost of care they provide is } \\
\text { higher than colleagues who care for similar } \\
\text { patients }\end{array}$ & $\begin{array}{l}\text { 5. Mudar a sua prática clínica (por exemplo: solicitação } \\
\text { de exames, prescrição) caso percebam que seus colegas } \\
\text { estejam atuando de forma mais custo-consciente }\end{array}$ \\
\hline $\begin{array}{l}\text { 6. Provide tests or treatments if a patient } \\
\text { requests them }\end{array}$ & $\begin{array}{l}\text { 6. Atender aos pedidos de exames ou tratamentos } \\
\text { solicitados pelo paciente }\end{array}$ \\
\hline $\begin{array}{l}\text { Indicate how much you agree or disagree with each } \\
\text { of the following statements: } \\
\text { 7. Physician clinical practices (e.g., ordering, } \\
\text { prescribing) are key drivers of high health care } \\
\text { costs }\end{array}$ & $\begin{array}{l}\text { Indique o quanto você concorda ou discorda com cada uma } \\
\text { das seguintes afirmações: } \\
\text { 7. As práticas clínicas do médico (solicitação de exames, } \\
\text { prescrição), são elementos chave dos altos custos em } \\
\text { cuidados de saúde. }\end{array}$ \\
\hline $\begin{array}{l}\text { 8. Cost to society should be important in } \\
\text { physician decisions to use or not to use an } \\
\text { intervention }\end{array}$ & $\begin{array}{l}\text { 8. O médico deve considerar o custo para a sociedade } \\
\text { antes de decidir usar ou não determinada intervenção }\end{array}$ \\
\hline $\begin{array}{l}\text { 9. The cost of a test or medication is only } \\
\text { important if the patient has to pay for it out of } \\
\text { pocket }\end{array}$ & $\begin{array}{l}\text { 9. O custo de um exame ou medicamento só é importante } \\
\text { se o paciente tiver de pagar por isso do próprio bolso. }\end{array}$ \\
\hline $\begin{array}{l}\text { 10. It is unfair to ask physicians to be cost- } \\
\text { conscious and still keep the welfare of their } \\
\text { patients foremost in their minds }\end{array}$ & $\begin{array}{l}\text { 10. É injusto pedir aos médicos que tenham mais } \\
\text { consciência dos custos e ainda assim manter o bem-estar } \\
\text { dos pacientes em primeiro lugar }\end{array}$ \\
\hline $\begin{array}{l}\text { 11. Cost-effectiveness data should be used to } \\
\text { determine what treatments are offered to } \\
\text { patients }\end{array}$ & $\begin{array}{l}\text { 11. Dados de custo-efetividade devem ser usados para } \\
\text { determinar quais tratamentos serão oferecidos aos } \\
\text { pacientes }\end{array}$ \\
\hline $\begin{array}{l}\text { 12. Trying to contain costs is the responsibility } \\
\text { of every physician }\end{array}$ & $\begin{array}{l}\text { 12. Tentar conter custos é uma responsabilidade de todo } \\
\text { médico }\end{array}$ \\
\hline $\begin{array}{l}\text { 13. Managing health care resources for all } \\
\text { patients is compatible with physicians' } \\
\text { obligation to serve individual patients }\end{array}$ & $\begin{array}{l}\text { 13. É possível gerenciar os recursos de cuidados de } \\
\text { saúde para todos os pacientes, e ao mesmo tempo } \\
\text { atender as necessidades individuais de cada paciente }\end{array}$ \\
\hline
\end{tabular}

One of the requirements for factor analysis is to examine the factorability with the Kaiser-MeyerOlkin (KMO) which was 0.68 and the sphericity Bartlett test that was significant at the level of $p<$ 0.001 .

The parallel analysis was consistent with the retention of a maximum of two factors. However, the twofactor solution obtained through the EFA resulted in a non-empirically sustainable distribution, because four of the items had factor loadings higher than 0.3 in both factors (suggestive of ambiguity).
For this reason, an alternate solution composed of just one factor was tested. In the one-factor solution, the items 6 and 9 had low factor loadings and were excluded from the final version of the scale. The factor loadings for the one-factor solution are shown in Chart 2.

The 11 -item scale underwent a composite reliability test with a value of 0.77 and Cronbach alpha of 0.66 . 


\begin{tabular}{|c|c|}
\hline & $\begin{array}{l}\text { Factor } \\
\text { loadings }\end{array}$ \\
\hline 12. Trying to contain costs is the responsibility of every physician. & 0.64 \\
\hline 11. Cost-effectiveness data should be used to determine what treatments are offered to patients & 0.60 \\
\hline 8. Cost to society should be important in physician decisions to use or not to use an intervention & 0.60 \\
\hline $\begin{array}{l}\text { 13. Managing health care resources for all patients is compatible with physicians' obligation to } \\
\text { serve individual patients }\end{array}$ & 0.52 \\
\hline 7. Physician clinical practices (e.g., ordering, prescribing) are key drivers of high health care costs & 0.47 \\
\hline 2. Try not to think about the cost to the health care system when making treatment decisions ${ }^{1}$ & -0.47 \\
\hline $\begin{array}{l}\text { 10. It is unfair to ask physicians to be cost-conscious and still keep the welfare of their patients } \\
\text { foremost in their minds. ? }\end{array}$ & -0.44 \\
\hline $\begin{array}{l}\text { 5. Change their clinical practices (e.g., ordering, prescribing) if the cost of care they provide is } \\
\text { higher than colleagues who care for similar patients }\end{array}$ & 0.42 \\
\hline 4. Talk to patients about the costs of care when discussing treatment options & 0.37 \\
\hline 3. Be aware of the costs of the tests or treatments they recommend & 0.37 \\
\hline 1. Take a more prominent role in limiting use of unnecessary tests & 0.34 \\
\hline 9. The cost of a test or medication is only important if the patient has to pay for it out of pocket 1,2 & -0.23 \\
\hline 6. Provide tests or treatments if a patient requests them ${ }^{2}$ & 0.14 \\
\hline
\end{tabular}

\section{Discussion}

A considerable proportion of healthcare costs can be attributed to medical attitudes ${ }^{16}$, especially overuse and waste of available resources. Most physicians acknowledge the importance of being cost-conscious, but it is difficult for most of them to play an active role in cost containment practices ${ }^{17}$.

Educational interventions to change the behavior of physicians towards more cost-conscious attitudes can be instituted from medical school. A validated measuring instrument can be useful to better plan and assess such educational interventions. Although some researchers are currently working on this subject, we found a lack of validated scales to measure this phenomenon among medical students.

The inclusion criteria for this research was that the participants were medical students in their two final years of medical school. These students are closer to medical activities and practical examples from other physicians. The sample was considered adequate to go ahead with the analysis, as it was representative of students of each period ${ }^{18}$.

The results suggest that the one-factor solution represents the best structure to measure the phenomena. Eleven of the 13 items in the scale had factor loadings higher than 0.3 and remained in the final version. The items number 9 "the cost of a test or medication is only important if the patient has to pay for it out of their own pocket" and number 6 "physicians should provide tests or treatments if a patient requests them" were excluded due to low factor loadings. These two items might be related to some content interpretation bias. Item number 6 , for example, can be mistaken with ignoring a patient's request. Even with the exclusion of these two items, it is considered that the content of the scale was not affected because the reduction corresponds to just $15 \%{ }^{19}$.

The composite reliability and Cronbach alpha were used to verify the internal consistency of the factors. The Cronbach alpha was considered as substantial ${ }^{15}$. However, few authors report some restrictions to its use as an indicator of consistency. One of them is the possibility of the Cronbach alpha being highly influenced by test length ${ }^{15}$. Literature demonstrates that alpha may be acceptable even when there are recognized problems with the scales and sometimes it is inappropriately used to claim an instrument is unidimensional $^{20}$. Therefore, the composite reliability index was used as it is recognized as being a more robust precision indicator than the Cronbach alpha ${ }^{21}$. The findings related to the scale reliability were not excellent but were considered acceptable. It is possible that the use of 4-point Likert scale could have reduced the scale reliability because in general, scales with few numbers of categories can result in lower variability and reliability ${ }^{22}$. However, 
it was considered important to maintain the same number of categories as in the original survey so as to facilitate future comparisons.

It is important to note some limitations of this study. Among them is the fact that the students were from a single medical school and selected by convenience. Confirmatory factor analysis could be used to increase the reliability of the findings

The results obtained from this study present an important contribution to the subject of costconsciousness in medical education. It is recommended that the instrument developed in this study be used not only in research but also to help to identify problems in specific groups and to assess results after educational interventions. The continuous use of the instrument can also create opportunities to retest it for new groups and institutions, which can provide further evidence for its validity and reliability.

\section{Conclusion}

The results suggest that the questionnaire is of a satisfactory psychometric quality and is capable of measuring medical students' perceptions of costconsciousness.

\section{Competing interests}

No financial, legal or political competing interests with third parties (government, commercial, private foundation, etc.) were disclosed for any aspect of the submitted work (including but not limited to grants, data monitoring board, study design, manuscript preparation, statistical analysis, etc.).

\section{References}

1. Wolfson D, Santa J, Slass L. Engaging Physicians and Consumers in Conversations About Treatment Overuse and Waste: A Short History of the Choosing Wisely Campaign. Acad Med. 2014;89(7):990-5. doi: 10.1097/ ACM.0000000000000270
2. Colla CH, Kinsella EA, Morden NE, Meyers DJ, Rosenthal $M B$, Sequist TD. Physician Perceptions of Choosing Wisely and Drivers of Overuse. American Journal of Managed Care. $2016 ; 22(5)$.

3. Levinson W, Huynh T. Engaging physicians and patients in conversations about unnecessary tests and procedures: Choosing Wisely Canada. CMAJ. 2014;186(5):325-6. doi: 10.1503/cmaj.131674

4. Rede Interagencial de Informações para a Saúde. Indicadores básicos para a saúde no Brasil: conceitos e aplicações. 2.ed. Brasília: Organização Pan-Americana da Saúde; 2008.

5. Levinson W, Kallewaard M, Bhatia RS, Wolfson D, Shortt $S$, Kerr EA. 'Choosing Wisely': a growing international campaign. BMJ Qual Saf. 2015;24(2):167-74. doi: $\underline{10.1136 / \mathrm{bmiqs}-2014-003821}$

6. Menezes MS, Gusmão MM, Ladeia AMT, Aguiar CVN, Santos CMF, Correia LCL. Implementation of choosing wisely campaign in health courses in brazil - description of the first steps. Brazilian Journal of Medicine and Human Health. 2016;4(4):156-159. doi: 10.17267/2317-3386bimhh. $\underline{\mathrm{v} 4 \mathrm{i} 4.1193}$

7. Bovier PA, Martin DP, Perneger TV. Cost-consciousness among Swiss doctors: a cross-sectional survey. BMC Health Serv Res. 2005;5:72. doi: 10.1186/1472-6963-5-72

8. Tilburt JC, Wynia MK, Sheeler RD, Thorsteinsdottir B, James KM, Egginton JS et al. Views of US physicians about controlling health care costs. JAMA. 2013;310(4):380-8. doi: 10.1001/iama.2013.8278

9. Goold SD, Hofer T, Zimmerman M, Hayward RA. Measuring physician attitudes toward cost, uncertainty, malpractice, and utilization review. J Gen Intern Med. 1994;9(10):544-9.

10. Ryskina KL, Halpern SD, Minyanou NS, Goold SD, Tilburt JC. The role of training environment care intensity in US physician cost consciousness. Mayo Clin Proc. 2015;90(3):31320. doi: $10.1016 /$ i.mayocp.2014.12.005

11. Hunderfund ANL, Dyrbye LN, Starr SR, Mandrekar J, Naessens JM, Tilburt JC et al. Role Modeling and Regional Health Care Intensity: U.S. Medical Student Attitudes Toward and Experiences With Cost-Conscious Care. Acad Med. 2016;92(5):694-705. doi: 10.1097/ ACM.0000000000001223

12. Tsang S, Royse CF, Terkawi AS. Guidelines for developing, translating, and validating a questionnaire in perioperative and pain medicine. Saudi J Anaesth. 2017;1 1 (Suppl 1):S809. doi: $10.4103 /$ sja.SJA 20317 
13. Everitt BS. Multivariate Analysis: the Need for Data, and other Problems. Br J Psychiatry. 1975;1 26(3):237-40.

14. Damásio BF. Uso da análise fatorial exploratória em psicologia. Avaliação Psicológica. 201 2; 1 1 (2):213-28.

15. Landis JR, Koch GG. The measurement of observer agreement for categorical data. Biometrics. 1977;33(1):15974.

16. Pritchard D, Petrilla A, Hallinan S, Taylor Junior DH, Schabert VF, Dubois RW. What Contributes Most to High Health Care Costs? Health Care Spending in High Resource Patients. J Manag Care Spec Pharm. 2016;22(2):102-9. doi: 10.18553/imcp.2016.22.2.102

17. Fletcher T. The impact of physician entrepreneurship on escalating health care costs. J Am Coll Radiol. 2005;2(5):41 14. doi: $10.1016 /$ i.jacr.2005.01.005

18. Hulley SB, Cummings SR, Browner WS. Designing Clinical Research. 4.ed. Philadelphia: Lippincott Williams \& Wilkins; 2013.

19. Morgado FFR, Meireles JFF, Neves CM, Amaral ACS, Ferreira MEC. Scale development: ten main limitations and recommendations to improve future research practices. Psicologia: Reflexão e Crítica. 2017;30. doi: 10.1186/ s41155-016-0057-1

20. Taber KS. The Use of Cronbach's Alpha When Developing and Reporting Research Instruments in Science Education. Research in Science Education. 2017. doi: 10.1007/s 11165 016-9602-2

21. Valentini F, Damásio BF. Variância Média Extraída e Confiabilidade Composta: Indicadores de Precisão. Psicologia: Teoria e Pesquisa. 2016;32(2):1-7. doi: 10.1590/0102-3772e322225

22. Dalmoro $M$, Vieira KM. Dilemas na construção de escalas Tipo Likert: o número de itens e a disposição influenciam nos resultados? Revista Gestão Organizacional. 2014;6(3):161 174. 